\title{
Integration of ICT in academic and administrative management processes
}

\author{
Edwin Martinez-Alvarez ${ }^{1}$, María del Carmen Rosa Coronado ${ }^{2}$, Judith Soledad Yangali Vicente ${ }^{3}$ \\ ${ }^{1}$ Universidad Norbert Wiener \\ ${ }^{2}$ Universidad Metropolitana de Educación, Ciencias y Tecnología \\ ${ }^{3}$ Universidad Norbert Wiener \\ 1edwinmartinez1104@gmail.com, ${ }^{2}$ coroma70@gmail.com, ${ }^{3}$ judith.yangali@wiener.edu.pe
}

\begin{abstract}
The main purpose of the research was to determine the direct relationship that exists between the integration of ICT with academic management and administrative management in Colombian educational institutions. In the integration of ICT, academic and administrative management are determining factors for the improvement of quality in the learning-teaching process in an educational institution, it is there where the importance of a curriculum design, pedagogical practices and management lies. of classroom directed to the implementation of technological tools where creativity and innovation of students and teachers are promoted, making the school an attractive and attractive setting for education. The investigation was raised from a quantitative approach, as for the method used in the investigation the hypothetical - deductive method was used, to collect the information the survey technique was applied and three questionnaires with a Likert-type scale were developed as instruments. Pearson's correlation coefficient $(\alpha=0.05)$ was used for the data analysis method. The population consisted of 185 teachers of elementary, secondary and middle school from eight educational institutions in the district of Turbo, Colombia. Concluding that there is a significant relationship between the integration of ICT and academic and administrative management in educational institutions in the district of TurboAntioquia, Colombia.
\end{abstract}

Index Terms

ICT, academic management, administrative management, integration, pedagogical practices

Article Received: 10 August 2020, Revised: 25 October 2020, Accepted: 18 November 2020

\section{Introduction}

It is evident the need of today's society to interact through the use of new technologies, increasingly, the knowledge society drives the mandatory use of these technologies in more areas and aspects of humanity and the educational field is no exception. [1] [2]. The integration of ICT in learning and teaching processes in recent years has shown a low impact on the quality of education. Although the opportunities offered by the use of ICTs in education are well known, the results of the OECD study entitled "Students, computers and learning: making the connection" show that, despite the investments made in technology for more than three decades, the results are not sufficiently congruent with the low impact on learning and teaching processes [3] [4].

According to figures from the Ministry of ICT in Colombia, ICT accessibility has increased by $80 \%$ in recent years in educational establishments and many of these new technologies have reached official schools, thanks to state programmes such as Vive Digital and Computadores para Educar [5]. However, the incorporation of new technologies into educational processes and their integration into the curriculum in an explicit and transversal manner in all subjects is still a pending task for teachers in Colombia [6] [7].

The purpose of the research is to analyse the relationship between the integration of ICT with the academic and administrative management processes in official educational institutions in Colombia, while each educational institution tends (or should tend) to improve the learning of its students by harmoniously implementing ICT and, at the same time, making important efforts to obtain and improve a technological infrastructure and training teachers, students and managers in the pedagogical uses of ICT [3].

However, the way in which students access and process information has changed, largely due to the emergence of ICT resources and tools, which have made knowledge globalised and the use of digital environments for the acquisition of knowledge without the limitations of space and time, which favours collective learning that is enriched through digital social interaction [8]. This can be clearly evidenced when analysing the social consequences of the pandemic caused by the appearance of the new coronavirus (SARS-CoV-2); within which, the situation of social isolation implemented by most of the affected countries as this problem became an opportunity for education to transform the implementation of traditional methodologies to innovative methodologies through the use of learning and teaching environments self-regulated by technologies [9]. The importance of the research lies in the contribution to the improvement of pedagogical methods of learning and teaching by determining the influence and impact of academic and administrative management on the integration of ICT in educational institutions, focusing on the strengths and weaknesses of this integration and, based on the results, measures can be implemented for the management of technological infrastructure and the design of training programmes and/or teacher training in the pedagogical use of ICT that serve as a solid and viable methodological basis for the improvement of educational quality. 


\section{Theoretical Bases}

\section{A. Information and communication technologies (ICT)}

According to Cobo (2011), "Information and communication technologies are those technological devices whose uses include creating, modifying, storing and retrieving information, contributing to the generation of knowledge"[10]. For the purposes of this research, an operational definition of ICT is constructed which corresponds to those technological devices, equipment and tools for the transformation of educational practices, by means of three dimensions: ICT competences, technological infrastructure and didactic use of ICT.

ICT competences are evident from the evolution of the role of the school in today's society, it is necessary for teachers to develop certain social, pedagogical and emotional competences, which lead to improve their guiding role in the learning and teaching processes; such is the case of technological competences or ICT competences which are: "a set of basic skills and knowledge in the use of ICT to meet the new challenges of society [11] [12].

One of the main elements to achieve a reduction in the digital divide in the educational field corresponds to the technological infrastructure that consists of the possession of and access to different study environments enriched by ICT, equipment, connectivity and software and hardware elements intended for the development of teaching-learning practices [13]. For this reason, it is decisive to identify whether or not an adequate infrastructure with the quantity and quality necessary for optimal performance in the learning and teaching processes in an educational institution is in place [14].

In recent decades, ICTs have been playing an important role in the social, cognitive and emotional development of children and young people; for this reason, schools should make appropriate use of ICTs as teaching-learning techniques and procedures by teachers, i.e. as a didactic use of ICTs, which is aimed at improving the learning-teaching process in educational institutions [13] [15].

The Colombian Ministry of Education MEN (2008) defines academic management as: "A set of actions that the members of an institution carry out to ensure that students learn and develop the necessary competences for their personal, social and professional performance" [13]. From the perspective of the teaching role, which is evolving from a simple transmitter of knowledge to a facilitator of learning, academic management is constituted as the relationship between the processes of socio-educational reality, from which emanate pedagogical environments or contexts that give meaning to pedagogical praxis. In which, the action of the teacher predominates as a mediator of learning, the role of researcher in academic projects, the role of promoter and its social management [16] [17].

In an educational institution, curriculum design is the orientation of the learning-teaching process and must be designed and executed from a scientific-pedagogical approach, without improvisation in any of its components; starting from the process of structuring each of the elements of the curriculum, among which are the learning objectives and competences, the contents, the didactic strategies and the evaluation of learning [18] [19].
Pedagogical practice as a training space or environment located in context in which theory and praxis are harmoniously articulated, is aimed at promoting pedagogical reflection as a result of the execution of a set of collaborative actions that are implemented with the various educational actors to achieve their comprehensive training in such a way that this contributes to sustainable social development [20] [21].

Classroom management is understood as the actions taken by a teacher to create and maintain a learning environment conducive to the achievement of instructional objectives [22]. For this, it is essential that the teacher knows and knows how to implement a variety of teaching strategies, ranging from the physical organisation of the classroom, the existence of rules or behavioural agreements and performance indicators, the type of relationships that are developed to promote a good classroom environment, and the creativity and level of innovation that he/she has to attract students to any academic subject, keeping their attention as much as possible [23].

\section{B. Administrative management}

The guide for institutional improvement (Guide No. 34) defines administrative management as: "A group of actions that the members of an institution carry out to support academic management, the administration of the physical plant, services and resources, the management of human talent and adequate financial support" [13]. Another concept given to administrative management from a business perspective defines it as the process of creating an appropriate working environment for the individual and/or group work of employees, for which the manager plans, organises, directs, and controls effectively, efficiently and effectively, the use of human talent and financial and technological tools at all levels of an organisation in order to achieve the objectives or goals set. In the same vein, educational administration must be aware of the planning processes and stages for good management and to achieve the institution's proposed objectives [24].

The administration of the physical plant and resources refers to the process that seeks to guarantee good infrastructure and equipment conditions for the adequate provision of educational services, based on the maintenance, adaptation and beautification of the physical plant, monitoring the use of spaces, acquisition and maintenance of learning resources, supplies, equipment and maintenance of equipment [13].

Human resources plays an important role in the process of guaranteeing good working conditions and professional development for the people linked to the educational establishment, promoting continuous and quality education and training, support for research, coexistence and conflict management, and the well-being of human resources [13].

Financial support is a process that seeks to provide financial and accounting support for the proper development of the educational institution's activities, based on the efficient management of the annual budget of the Educational Services Fund under due fiscal control [13]. 


\section{Math}

The research is applied, under the hypothetical-deductive method, with a causal correctional level, the research design is non-experimental, cross-sectional. The study population is made up of 359 teachers from eight educational institutions in the District of Turbo, located in the department of Antioquia, Colombia. The sample is made up of 185 teachers at the primary, secondary and middle school levels. The technique used to obtain the data was a survey based on three questionnaire-type instruments containing items on the indicators and dimensions of the dependent variable ICT integration and the independent variables academic management and administrative management, which were applied to the teaching staff of educational institutions in the district of Turbo, Antioquia.

\section{Results And Discussion}

\section{A. Descriptive analysis of results variable 1}

Table: 1 Distribution of dimensions of variable 1

\begin{tabular}{llll}
\hline & Low & Medium & High \\
\hline ICT Competences & $8.6 \%$ & $24.9 \%$ & $66.5 \%$ \\
Technological & $11.4 \%$ & $56.2 \%$ & $32.4 \%$ \\
infrastructure & & & \\
Didactic use of ICT & $16.2 \%$ & $21.6 \%$ & $62.2 \%$ \\
\hline
\end{tabular}

Table 1 shows that, of the total of 185 teachers surveyed from the educational institutions in the district of TurboAntioquia-Colombia in 2020, 16 teachers $(8.6 \%)$ have a low level in the ICT competences dimension; 46 teachers $(24.9 \%)$ have a medium level, while 123 teachers $(66.5 \%)$ have a high level. As for the second dimension referring to technological infrastructure, 21 teachers $(11.4 \%)$ report a low level; 104 teachers $(56.2 \%)$ report a medium level; and 60 teachers $(32.4 \%)$ report a high level. On the third dimension referring to the didactic use of ICT, 30 teachers $(16.2 \%)$ had a low level; 40 teachers $(21.6 \%)$ had a medium level; while 115 teachers $(62.2 \%)$ had a high level.

\section{B. Descriptive analysis of results variable 2}

Table: 2 Distribution dimensions of variable 2

\begin{tabular}{llll}
\hline & Bajo & Medio & Alto \\
\hline Curriculum design & $5.4 \%$ & $37.8 \%$ & $56.8 \%$ \\
Pedagogical practices & $8.1 \%$ & $44.3 \%$ & $47.6 \%$ \\
Classroom management & $10.8 \%$ & $17.3 \%$ & $71.9 \%$ \\
\hline
\end{tabular}

Table 2 shows that, of the total of 185 teachers surveyed from the educational institutions in the district of TurboAntioquia in Colombia in 2020, 10 teachers representing $5.4 \%$ have a low level in the curriculum design dimension; 70 of the teachers surveyed, representing $37.8 \%$, have a medium level and 105 of the teachers surveyed, representing $56.8 \%$, have a high level. As for the second dimension of pedagogical practices, 15 teachers $(8.1 \%)$ showed a low level; 82 teachers $(44.3 \%)$ showed a medium level; while 88 teachers $(47.6 \%)$ showed a high level. As far as the third dimension of classroom management is concerned, 20 teachers representing $10.8 \%$ show a low level; 32 teachers representing $17.3 \%$ show a medium level; while 133 teachers representing $71.9 \%$ show a high level.

\section{Descriptive analysis of results variable 3}

Tabla: 3 Distribución dimensiones de la variable 3

\begin{tabular}{lrlll}
\hline & & Low & Medium & High \\
\hline $\begin{array}{l}\text { Management of } \\
\text { physical plant and }\end{array}$ & $5,9 \%$ & $53,0 \%$ & $41,1 \%$ \\
resources & & & & \\
Human resources & & $15,7 \%$ & $67,6 \%$ & $16,8 \%$ \\
Financial support & $29,7 \%$ & $52,4 \%$ & $17,8 \%$ \\
\hline
\end{tabular}

Table 3 shows that, of the total of 185 teachers surveyed from the educational institutions in the district of TurboAntioquia in Colombia in 2020, 11 teachers representing $5.95 \%$ have a low level in the dimension of administration of the physical plant and resources; 98 of the teachers surveyed, representing 52.97\%, have a medium level and 76 of the teachers surveyed, representing $41.08 \%$, have a high level. As for the second dimension of human talent, 29 teachers (15.68\%) showed a low level, 125 (67.57\%) showed a medium level, while $31(16.76 \%)$ showed a high level. Regarding the third dimension referring to financial support, 55 teachers representing $29.73 \%$ evidenced low level; 97 of the surveyed teachers representing $52.43 \%$ evidenced medium level; while 33 of the surveyed teachers representing $17.84 \%$ evidenced high level.

Table: 4 Distribution levels of variable 3

\begin{tabular}{llll}
\hline & & Frequency & Percentage \\
\hline \multirow{4}{*}{ Valid } & Low & 80 & 43,2 \\
& Medium & 101 & 54,6 \\
& High & 4 & 2,2 \\
& Total & 185 & 100,0 \\
\hline
\end{tabular}

Table 4 shows that, of the total of 185 teachers surveyed from the educational institutions in the district of TurboAntioquia, Colombia, 2020, 80 teachers, representing $43.2 \%$, showed a low level of administrative management; 101 , representing $54.6 \%$, showed a medium level; while only 4 teachers, representing $2.2 \%$, showed a high level.

Table: 5 General Hypothesis Testing

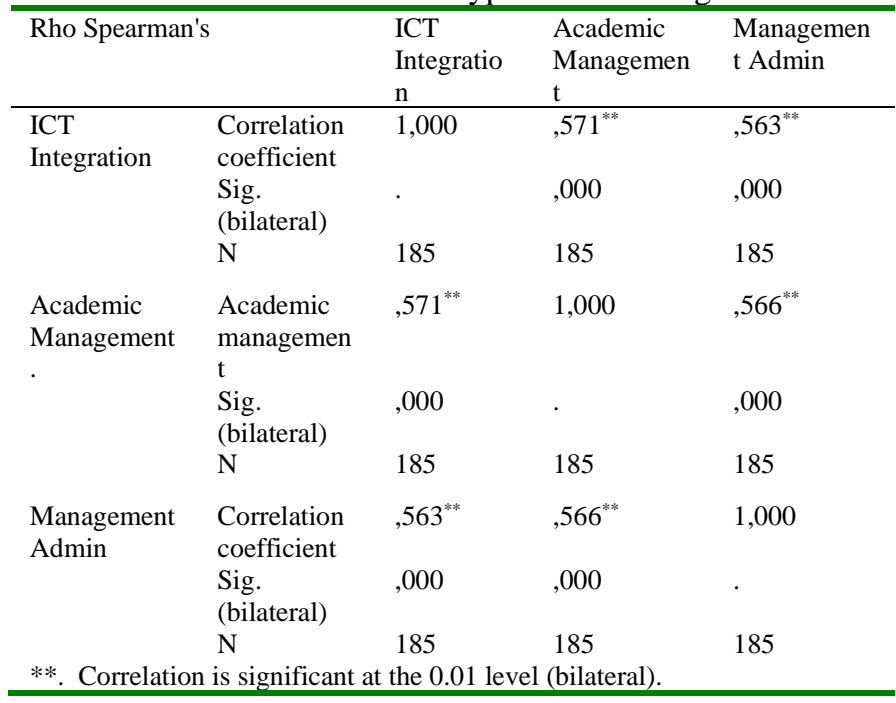


Table 5 shows that the significance value for academic and administrative management is $0.000<0.05$, therefore the null hypothesis is rejected and the alternative hypothesis is accepted, i.e. there is a significant relationship between ICT integration and academic and administrative management in educational institutions in the district of Turbo-Antioquia in Colombia during the year 2020.

It is also observed according to the value of Spearman's coefficient the degree of correlation between the integration of ICT with academic management is 0.571 , i.e. there is a good and positive relationship; while the degree of relationship between ICT and administrative management is 0.563 , also good and positive.

These results indicate that in order to achieve an optimal integration of ICT into the learning-teaching processes, adequate academic and administrative management is necessary, based on curricular design, pedagogical practices and financial support, which would be reflected in an improvement in the quality of education in an educational institution. These results are corroborated by Lubis [25], who in his research concluded that there is a significant relationship between the use of ICT and the quality of student learning processes. Likewise, Gómez [26] highlights the importance of having an up-to-date technological infrastructure available for classroom work.

Table: 6 Specific hypothesis test 1

\begin{tabular}{|c|c|c|c|c|}
\hline \multicolumn{2}{|l|}{ Rho Spearman's } & \multirow{2}{*}{$\begin{array}{l}\text { ICT } \\
\text { Integration } \\
1,000\end{array}$} & \multirow{2}{*}{$\begin{array}{l}\begin{array}{l}\text { Academic } \\
\text { Management }\end{array} \\
, 571^{* *}\end{array}$} & \multirow{2}{*}{$\begin{array}{l}\begin{array}{l}\text { Management } \\
\text { Admin }\end{array} \\
, 563^{* *}\end{array}$} \\
\hline $\begin{array}{l}\text { ICT } \\
\text { Integration }\end{array}$ & Correlation & & & \\
\hline & $\begin{array}{l}\text { Sig. } \\
\text { (bilateral) }\end{array}$ & . &, 000 &, 000 \\
\hline & $\mathrm{N}$ & 185 & 185 & 185 \\
\hline \multirow[t]{3}{*}{$\begin{array}{l}\text { Academic } \\
\text { Management. }\end{array}$} & $\begin{array}{l}\text { Correlation } \\
\text { coefficient }\end{array}$ &, $571^{* *}$ & 1,000 &, $566^{* *}$ \\
\hline & $\begin{array}{l}\text { Sig. } \\
\text { (bilateral) }\end{array}$ &, 000 & . & ,000 \\
\hline & $\mathrm{N}$ & 185 & 185 & 185 \\
\hline \multirow[t]{3}{*}{$\begin{array}{l}\text { Management } \\
\text { Admin. }\end{array}$} & $\begin{array}{l}\text { Correlation } \\
\text { coefficient }\end{array}$ &, $563^{* *}$ &, $566^{* *}$ & 1,000 \\
\hline & $\begin{array}{l}\text { Sig. } \\
\text { (bilateral) }\end{array}$ & ,000 &, 000 & . \\
\hline & $\mathrm{N}$ & 185 & 185 & 185 \\
\hline
\end{tabular}

Table 6 shows that the significance value for academic and administrative management is $0.000<0.05$, so the null hypothesis is rejected and the alternative hypothesis is accepted, i.e. there is a significant relationship between ICT competences and academic and administrative management in the educational institutions in the district of TurboAntioquia.

In this sense, when analysing these results, it is confirmed that the more knowledge teachers have about the use of ICT and the better the technological infrastructure of an educational institution, the better the integration of ICT into the curriculum design, pedagogical practices and classroom management, thus contributing to the self-construction of knowledge by students. For this reason, what is described by Marín [27], who states that educational institutions require strategies for the integration and articulation of innovative technologies that strengthen didactics in their teaching processes is confirmed.
Table: 7 Specific hypothesis test 2

\begin{tabular}{|c|c|c|c|c|}
\hline \multicolumn{2}{|l|}{ Spearman's Rho } & \multirow{2}{*}{$\begin{array}{l}\begin{array}{l}\text { Technological } \\
\text { infrastruct. } \\
\text { management }\end{array} \\
1,000\end{array}$} & \multirow{2}{*}{$\begin{array}{l}\begin{array}{c}\text { Academic } \\
\text { management }\end{array} \\
477^{* *}\end{array}$} & \multirow{2}{*}{$\begin{array}{l}\text { Admin. } \\
\text { management }\end{array}$} \\
\hline $\begin{array}{l}\text { Technological } \\
\text { infrastructure }\end{array}$ & $\begin{array}{l}\text { Coeficiente } \\
\text { de } \\
\text { correlación }\end{array}$ & & & \\
\hline & $\begin{array}{l}\text { Sig. } \\
\text { (bilateral) }\end{array}$ & & ,000 & , 000 \\
\hline & $\mathrm{N}$ & 185 & 185 & 185 \\
\hline \multirow[t]{3}{*}{$\begin{array}{l}\text { Academic } \\
\text { management }\end{array}$} & $\begin{array}{l}\text { Coeficiente } \\
\text { de } \\
\text { correlación }\end{array}$ & , $477^{* *}$ & 1,000 &, $566^{* *}$ \\
\hline & $\begin{array}{l}\text { Sig. } \\
\text { (bilateral) }\end{array}$ & ,000 & . & ,000 \\
\hline & $\mathrm{N}$ & 185 & 185 & 185 \\
\hline \multirow[t]{3}{*}{$\begin{array}{l}\text { Management } \\
\text { Admin. }\end{array}$} & $\begin{array}{l}\text { Coeficiente } \\
\text { de } \\
\text { correlación }\end{array}$ &, $477^{* * *}$ &, $566^{* *}$ & 1,000 \\
\hline & $\begin{array}{l}\text { Sig. } \\
\text { (bilateral) }\end{array}$ & , 000 & , 000 & \\
\hline & $\mathrm{N}$ & 185 & 185 & \\
\hline
\end{tabular}

Table 7 shows that the significance value for academic and administrative management is $0.000<0.05$, therefore the null hypothesis is rejected and the alternative hypothesis is accepted, i.e. there is a significant relationship between technological infrastructure and academic and administrative management in educational institutions in the district of Turbo-Antioquia. This shows that the possession of and access to technological equipment, devices and services is related to good academic and administrative management in an educational institution.

These results contrast with those obtained by Carrasco [28], who concludes that the technological infrastructure implemented and the use of educational software have a significant influence on the pedagogical performance of secondary school teachers. In addition, Arenas [29], mentions that financial support is needed from the administrative management in terms of investment in technological infrastructure through the provision of equipment, devices, internet connection and computer laboratories to promote access and pedagogical use of ICT.

Table: $\mathbf{8}$ Specific hypothesis test 3

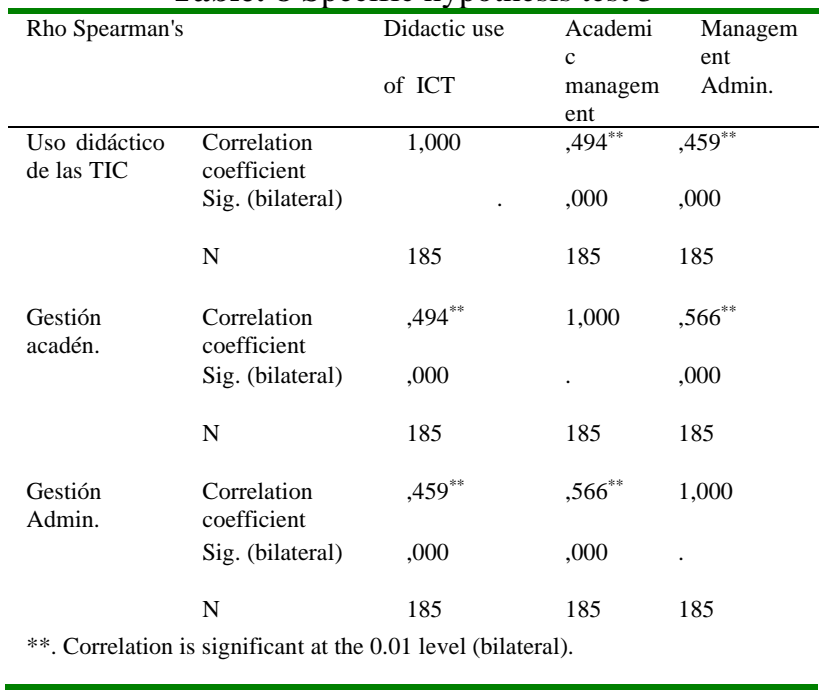

Table 8 shows that the significance value for academic and administrative management is $0.000<0.05$, therefore the null hypothesis is rejected and the alternative hypothesis is 
accepted, i.e. there is a significant relationship between the didactic use of ICT and academic and administrative management in educational institutions in the district of Turbo-Antioquia, Colombia, 2020. From these results, it can be inferred that for an adequate and explicit didactic use of ICT in the learning and teaching processes, good academic and administrative management is necessary in an educational institution.

In this regard, Bautista-Rico [30] states that, with the didactic use of ICT in regular work, the student's training is complemented and becomes attractive and innovative, helping to achieve the expected learning achievements and acquisition of competences; therefore, the intentional and professional action of the teacher in planning the use of technological resources in the learning-teaching process is necessary. However, the administration should manage the constant and quality training and/or education of teachers in the pedagogical integration of ICT, with a view to strengthening and developing technological competences and their application in the educational process.

\section{Conclusion}

With regard to the general objective, it is concluded that there is a significant relationship between the ICT integration variable and the academic and administrative management variables. With regard to the specific objectives, it is concluded that there is a relationship between the dimensions ICT competences, technological infrastructure and didactic use of ICT and the variables academic management and administrative management, and that this contributes to the achievement of institutional objectives for the improvement of educational quality in the educational institutions of the district of Turbo-Antioquia in Colombia.

According to the general results obtained with Spearman's correlation statistic, the ICT integration variable presented a value of .571 and .563 of correlation with the academic management and administrative management variables respectively. Therefore, it is concluded that the academic and administrative management in an educational institution is decisive for an adequate integration of ICT into the pedagogical processes in the educational institutions of the district of Turbo-Antioquia in Colombia, during the year 2020.

\section{References}

[1] D. Jonassen, "Procesos de aprendizaje mediante las TIC", Universitat Oberta de Catalunya, 2003.

[2] O. Y. Aparicio, "Las TIC como herramientas cognitivas", Rev. Interamericana de Investigación, Educación, vol. 11, no 1, pp. 67-80. July 2018.

[3] A. Cortés, "Políticas públicas para la integración de las TIC en educación.
Educación y Ciudad", no 33, pp. 75-86, 2017.

[4] IESME, "Estudio sobre la inclusión de las TIC en los centros educativos de aulas fundación telefónica", Grafilia S.L., 2018.

[5] MinTIC, "Informe de Gestión al Congreso de la República 2018-2019", 2019.

[6] R. A. García, F. H. Fernández, and J. E. Duarte, "Modelo de integración de las TIC en instituciones educativas con características rurales", Revista Espacios, vol. 38, no 50, pp. 26-40, July 2017.

[7] A. A. Gamboa, C. A. Hernández, and R. Prada, "Práctica pedagógica $\mathrm{y}$ competencias TIC: atributos y niveles de integración en docentes de instituciones educativas de básica y media", Saber, Ciencia Y Libertad, vol. 13, no 1, pp. 258274, Jan. 2018.

[8] I. Artime, and A. Gutiérrez, "Situated learning in the design of virtual learning environments: a peer learning experience in a community of practice", Aula Abierta, vol. 47, no 3, pp. 347-354, July 2018.

[9] UN, "Goal 4: Ensure inclusive and equitable quality education and promote lifelong learning opportunities for all", 2020.

[10] J. C. Cobo, "The concept of information technologies. Benchmarking on definitions of ICTs in the knowledge society", In ZerRevista de Estudios de Comunicación, vol. 14, no 27, pp. 295-318, 2009.

[11]F. Esteve, "La competencia digital docente: más allá de las habilidades TIC" [web log post], Feb. 2014.

[12] M. Careaga, and A. Veloso, "Estándares y competencias TIC para la formación inicial de profesores", REXE-Revista de Estudios y Experiencias en Educación, vol. 6, no 12, pp. 93-106, 2016.

[13] MEN, "Guía para el mejoramiento institucional de la autoevaluación al plan de mejoramiento", 2008.

[14] L. Sánchez, A. M. Reyes, D. Ortiz, and F. Olarte, "El rol de la infraestructura tecnológica en relación con la brecha 
digital y la alfabetización digital en 100 instituciones educativas de Colombia. Calidad en la educación", no 47, pp. 112144, Aug. 2017.

[15] M. P. García, I. M. Solano, and M. M. Sánchez, "Uso didáctico de las TIC en los colegios rurales agrupados de la Región de Murcia", Revista Interuniversitaria De Investigación En Tecnología Educativa, no 5, pp. 102-115, Dec. 2018.

[16] A. N. Inciarte, N. Marcano, and M. E. Reyes, "Gestión académico- administrativa en la educación básica", Revista Venezolana de Gerencia, vol. 11, no 1, pp. 221-243, April-June 2006.

[17] S. M. Viveros, and L. Sánchez, "La gestión académica del modelo pedagógico sociocrítico en la institución educativa: rol del docente", Revista Universidad y Sociedad, vol. 10, no 5, pp. 424-433, Dec. 2018.

[18] V. Santiváñez, "Diseño curricular a partir de competencias", Ediciones de la U, 2013.

[19] J. J. Fonseca, and M. E. Gamboa, "Aspectos teóricos sobre el diseño curricular y sus particularidades en las ciencias", Revista Boletín Redipe, vol. 6, no 3, pp. 83- 112, Mar 2017.

[20] S. Tobón, J. E. Martínez, E. Valdez, and T. Quiriz, "Prácticas pedagógicas: Análisis mediante la cartografía conceptual", Revista Espacios, vol. 39, no 53, pp. 3146, Nov. 2018.

[21] B. Vanegas, and A. Fuentealba, "Identidad profesional docente, reflexión y práctica pedagógica: Consideraciones claves para la formación de profesores: Perspectiva Educacional", vol. 58, no 1, pp. 115-138, Aug. 2019.

[22] P. LePage, L. Darling-Hammond, H. Akar, C. Gutiérrez, E. Jenkins-Gunn, and K. Rosebrock, "Classroom management. In L. Darling-Hammond and J. Bransford (Eds.), Preparing teachers for a changing world: What teachers must learn and be able to do", p. 327-357, John Wiley \& Sons, 2005.
[23] P. M. Uruñuela, "La gestión del aula: todo lo que me hubiera gustado saber cuando empecé a dar clase" vol. 153, Narcea Ediciones, 2019.

[24] H. Koontz, H. Weihrich, and M. Cannice, "Management: A global and business perspective", Mcgraw-Hill/Interamericana Editores S.A, 2012.

[25] A. H. Lubis, S. Z. S. S. Idrus, and A Sarji, "ICT usage among teachers and its impact on the quality of the learning process (trans.)", Jurnal Komunikasi: Malaysian Journal of Communication, vol. 34, no 1, pp. 284-299, 2018.

[26] Y. Gómez, "Modelo de gestión de infraestructura de TI como apoyo en los procesos de enseñanza en docentes de la institución educativa niño Jesús de Praga del Bajo Calima en el distrito de Buenaventura", Universidad nacional abierta y a distancia, 2019.

[27] F. V. Marín, A. D. Inciarte, H. G. Hernández, and R. C. Pitre, "Estrategias de las Instituciones de Educación Superior para la Integración de las Tecnología de la Información y la Comunicación y de la Innovación en los Procesos de Enseñanza: Un Estudio en el Distrito de Barranquilla", Formación universitaria, vol. 10, no 6, Dec. 2017.

[28] M. E. Carrasco, "Infraestructura tecnológica implementada y uso de softwares educativos en el desempeño pedagógico docente del nivel secundario de la IE Politécnico Nacional del Callao, 2017", Universidad César Vallejo, 2018.

[29] S. M. Arenas, "Uso de las TIC para incrementar la calidad educativa en la institución educativa Santa María Goretti de Bucaramanga, Colombia en el año 2017", Universidad Privada Norbert Wiener, 2018.

[30] R. Y. Bautista-Rico, "El uso didáctico de las TICS en el mejoramiento de la labor didáctica en la escuela colombiana", Aibi revista investigación, administración e ingeniería, vol. 5, no 2, pp. 2-8, July 2017. 